\title{
Kinetic analysis of IFIT1 and IFIT5 interactions with different native and engineered RNAs and its consequences for designing mRNA-based therapeutics
}

\author{
BEATA MIEDZIAK, ${ }^{1}$ ANNA DOBIEŻYŃSKA, ${ }^{1}$ ZBIGNIEW M. DARŻYNKIEWICZ, ${ }^{1,2}$ JULIA BARTKOWSKA, ${ }^{1,2}$ \\ JOANNA MISZKIEWICZ, ${ }^{1,3}$ JOANNA KOWALSKA, ${ }^{2}$ MARCIN WARMINSKI, ${ }^{2}$ MICHAL TYRAS, ${ }^{1,3}$ \\ JOANNA TRYLSKA, ${ }^{1}$ JACEK JEMIELITY, ${ }^{1}$ EDWARD DARZYNKIEWICZ, ${ }^{1,2}$ and RENATA GRZELA ${ }^{1}$ \\ ${ }^{1}$ Centre of New Technologies, University of Warsaw, 02-097 Warsaw, Poland \\ ${ }^{2}$ Division of Biophysics, Institute of Experimental Physics, Faculty of Physics, University of Warsaw, 02-097 Warsaw, Poland \\ ${ }^{3}$ College of Inter-Faculty Individual Studies in Mathematics and Natural Sciences, University of Warsaw, 02-097 Warsaw, Poland
}

\begin{abstract}
In response to foreign RNA, cellular antiviral mechanisms stimulate high expression of interferon-induced proteins with tetratricopeptide repeats (IFITs). Two members of the IFIT protein family, IFIT1 and IFIT5, are capable of binding the very terminal $5^{\prime}$ end of mRNA. In eukaryotes, these mRNA termini contain a cap structure $\left(\mathrm{m}^{7} \mathrm{GpppN}\right.$, cap 0 ) that is often subjected to further modifications. Here, we performed a thorough examination of IFIT1 and IFIT5 binding to a wide spectrum of differently capped as well as fully uncapped mRNAs. The kinetic analysis of IFIT1 and IFIT5 interactions with mRNA ligands indicates that the cap structure modifications considerably influence the stability of IFIT1/RNA complexes. The most stable complexes were formed between IFIT1 and GpppG/A- and $\mathrm{m}^{7} \mathrm{GpppG} / \mathrm{A}-\mathrm{RNAs}$. Unexpectedly, we found that NAD ${ }^{+}$- and NADH-capped RNAs associate with IFIT5 with kinetic parameters comparable to pppG-RNA. Finally, we measured interactions of IFIT1 with mRNAs bearing modified synthetic cap analogs that start to become the important tools in biotechnological and medicinal research. We found that incorporation of modified cap analogs to the RNA protects the latter, to a certain degree, from the translational inhibition caused by IFIT1 protein.
\end{abstract}

Keywords: IFIT; innate immunity; kinetic; mRNA; synthetic cap

\section{INTRODUCTION}

mRNAs of eukaryotes possess a $5^{\prime}$ terminal structure of 7methylguanosine linked to the RNA by $5^{\prime}$ to $5^{\prime}$ triphosphate bridge ( $m^{7} \mathrm{GpppN}$, cap 0$)$. This structure affects diverse aspects of RNA biology, for example, regulates nuclear export and splicing, enhances mRNA translation, and protects transcripts from degradation. The cap structure is conserved among all eukaryotes, but in higher eukaryotes it has a more complex methylation pattern with 2'-O-ribose methylation occurring in the first, or the first and the second, transcribed nucleotides resulting in cap 1 $\left(m^{7} G p p p N^{1} m^{2}\right)$ or cap $2\left(m^{7} G p p p N^{1} m^{2} m\right)$ mRNA, respectively (Bélanger et al. 2010; Werner et al. 2011). Moreover, beside the canonical $\mathrm{m}^{7} \mathrm{G}$ cap, a number of atypical RNA 5 '-end modifications has recently been discovered. Intensively studied examples are nicotinamide adenine dinucleotide $\left(\mathrm{NAD}^{+}\right)$- and its reduced form

Corresponding author: r.grzela@cent.uw.edu.pl

Article is online at http://www.rnajournal.org/cgi/doi/10.1261/rna. 073304.119.
NADH-capped RNA identified in humans and other eukaryotes (Kowtoniuk et al. 2009; Jiao et al. 2017; Walters et al. 2017; Wang et al. 2019). RNAs capped with NAD ${ }^{+}$ and $\mathrm{NADH}$ account for respectively up to $50 \%$ and up to $40 \%$ of mitochondrial RNAs (Bird et al. 2018).

It has been shown that methylations of $N^{1}$ and $N^{2}$ nucleotides function as a molecular signature and transcripts missing them trigger antiviral innate immune responses (Daffis et al. 2010; Züst et al. 2011; Abbas et al. 2017). "Nonself" mRNA is recognized by diverse endosomal Toll-like receptors (TLR3, TLR7, TLR8), cytoplasmic receptors like the RNA-activated protein kinase $(P K R)$, retinoic acidinducible gene I protein (RIG-I), melanoma differentiationassociated protein 5 (MDA 5), 2'-5' oligoadenylate synthase (OAS) and nucleotide-binding oligomerization domain-containing protein 2 (NOD2) (Yoneyama et al.

(c) 2020 Miedziak et al. This article is distributed exclusively by the RNA Society for the first 12 months after the full-issue publication date (see http://rnajournal.cshlp.org/site/misc/terms.xhtml). After 12 months, it is available under a Creative Commons License (Attribution-NonCommercial 4.0 International), as described at http:// creativecommons.org/licenses/by-nc/4.0/. 
2004, 2005; Pichlmair et al. 2006; Schlee et al. 2009). Once these receptors are triggered, they induce inflammation associated with type I interferon, activate proinflammatory cytokines, chemokines, and cascades of transcriptional programs. Among the most potently expressed innate immune effectors are interferon-induced proteins with tetratricopeptide repeats or IFITs. There are five well-characterized human paralogs, namely IFIT1, IFIT1B, IFIT2, IFIT3, and IFIT5. Characteristic features of these proteins are tetratricopeptide repeat (TPR) motifs forming amino- and carboxy-terminal globular domains connected by a flexible linker. IFIT1 and IFIT5 form a groove or pocket in between the $\mathrm{N}$ and $\mathrm{C}$ domains which is positively charged and responsible for binding of single-stranded RNA (Yang et al. 2012; Abbas et al. 2013; Feng et al. 2013; Katibah et al. 2013). In turn, IFIT2 and IFIT3 have the propensity to interact with IFIT1 thus enhancing its RNA-binding activity (Pichlmair et al. 2011; Habjan et al. 2013). Direct binding of the IFIT proteins to the $5^{\prime}$ end of viral RNAs was associated with a disruption of virus replication (Pichlmair et al. 2011).

Despite high sequence identity (55\%) and an early suggestion that IFIT1 and IFIT5 bind RNA in a similar fashion, crystal structures revealed important differences at the entrance and inside of the cap-binding pocket (Abbas et al. 2017). It was shown that pppRNA is bound to both IFIT1 and IFIT5 via numerous electrostatic interactions formed between triphosphate moiety and protein side chains. However, IFIT5 recognition of pppRNA is mediated by a charged metal ion coordinating the $\alpha$ - and $\gamma$-phosphates and stabilizing the conformation of triphosphate, while in IFIT1 this function is performed by Arg38. The positively charged RNA-binding tunnel in IFIT1 is also more extended than the one in IFIT5 and includes an additional hydrophobic pocket which can accommodate $N^{7}$-methylguanosine moiety in multiple conformations (Abbas et al. 2017). This structural organization renders IFIT1 specialization in capped-RNA binding while the IFIT5 primary role is rather limited to recognition of pppRNA.

Thus far, the studies on IFIT-RNA specificity were performed mainly using biochemical techniques which yielded approximate estimates of binding affinity. The initial study on IFIT1 demonstrated, similarly to IFIT5, binding to 5' pppRNA (Pichlmair et al. 2011). Subsequent investigations showed IFIT1 preferential binding to $\mathrm{m}^{7} \mathrm{GpppRNA}$ (Kimura et al. 2013; Kumar et al. 2014), or unmethylated GpppRNA (Habjan et al. 2013) and no or minimal binding to $m^{7} G p p p N^{1} m R N A$. Recently, it has been shown that even RNAs bearing caps methylated alone on position $N^{1}\left(m^{7} G p p p N^{1} m\right)$ or $N^{2}\left(m^{7} G p p p N^{1} N^{2} m\right)$ were still able to interact with IFIT1 (Abbas et al. 2017). Only the combination of both $N^{1}$ and $N^{2}$ methylations protected the transcripts from binding through IFIT1 (Abbas et al. 2017). In turn, IFIT5 protein was reported to bind pppRNA and tRNA but not OH-RNA, pRNA nor $\mathrm{m}^{7} \mathrm{GpppRNA}$ (Abbas et al. 2013; Feng et al. 2013; Habjan et al. 2013; Katibah et al. 2013, 2014; Kumar et al. 2014). In contrast to these studies, Katibah et al. (2014) showed IFIT5 ability to strongly bind $p R N A$ as well as $m^{7} G p p p R N A$.

The IFIT1 protein efficiently outcompetes the binding of the translation initiation complex elF4F onto the $\mathrm{m}^{7} \mathrm{GpppRNA}$ and thus prevents the subsequent assembly of the translation machinery and inhibition of protein synthesis (Habjan et al. 2013; Kumar et al. 2014). This allows a specific block of RNA viruses lacking 2'O-methyltransferases whereas progression of the antiviral response in infected cells can be maintained.

Furthermore, it has been shown that not only viral but also in vitro synthesized (IVT) mRNAs when introduced into the cell can trigger an antiviral innate immune response resulting in translation arrest and accelerated decay of exogenous transcripts (Devoldere et al. 2016; Loomis et al. 2016). Both the shutdown of protein synthesis and degradation of mRNA present a major obstacle in development of mRNA-based therapeutics. However, new advances in messenger RNA technologies made it possible to increase transcript stability and obtain a high translation efficiency (Sahin et al. 2014; Vallazza et al. 2015). One of these tools for engineering of RNAs adaptable for biotechnological and medical applications are synthetic cap analogs. Particularly interesting are anti-reverse cap analog (ARCA, $m_{2}{ }^{7,2^{\prime}-O} \mathrm{GpppG}$ and $\mathrm{m}_{2}{ }^{7,3^{\prime}-\mathrm{O}} \mathrm{GpppG}$ ) - the first cap dinucleotide that allowed proper incorporation during in vitro transcription (Stepinski et al. 2001; Jemielity et al. 2003) and its derivative $\beta$-S-ARCA $\left(m_{2}{ }^{7,2^{\prime}-O} \mathrm{Gpp} s \mathrm{pG}\right)$ further modified within the phosphate bridge to provide resistance to decapping enzymes (Grudzien-Nogalska et al. 2007). ARCA is already being broadly used in basic research while $\beta$-S-ARCA is now in clinical trials as a part of an anti-cancer vaccine for treatment of melanoma, breast, colon, lung, and prostatic cancer. RNA has more applications than vaccine and could be used to treat a wide spectrum of diseases. RNA-based molecule may be a carrier in protein replacement therapy or stem cell reprogramming. But for these applications the inherent immunogenicity of IVT mRNA, which is beneficial in the case of its usage as a vaccine, should be reduced. Thus, information about an effect of modified cap analogs on induction and interaction with cellular proteins engaged in immunologic response, for example, effector IFIT1, are highly desired.

Despite a significant number of studies aiming at elucidating the molecular recognition preferences of IFIT1 and IFIT5, only limited quantitative data on binding affinities for variously capped RNAs are available. Moreover, apart from the canonical $m^{7} G$ cap, the recognition by IFIT proteins of the atypical RNA $5^{\prime}$-end modifications and various synthetic $5^{\prime}$-caps have never been investigated. Therefore, in this study, we developed a biophysical assay allowing the monitoring of direct RNA-protein binding. This test was used for studying IFIT1 and IFIT5 interaction with a spectrum of differently capped RNAs (Fig. 1). 


\section{G- and $m^{7} G$-Capped RNA}
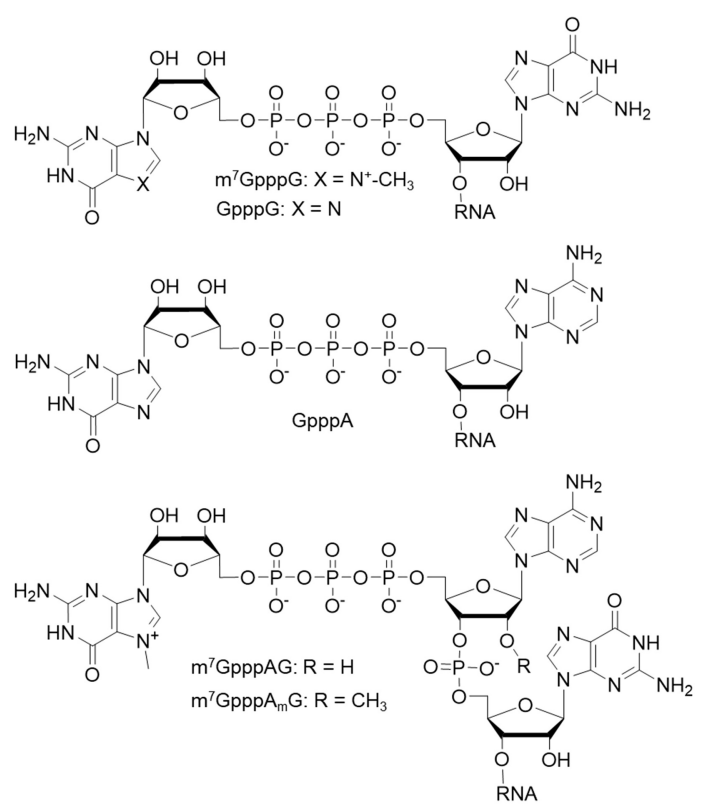

\section{Uncapped RNA}
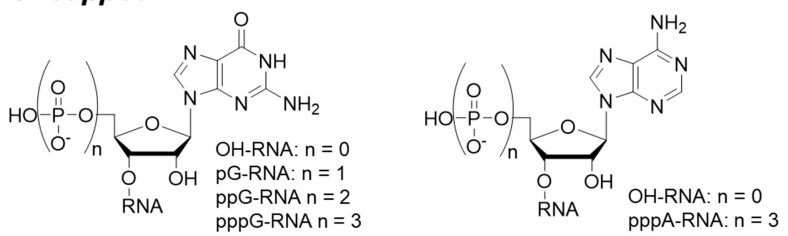

\section{Chemically modified capped RNA}
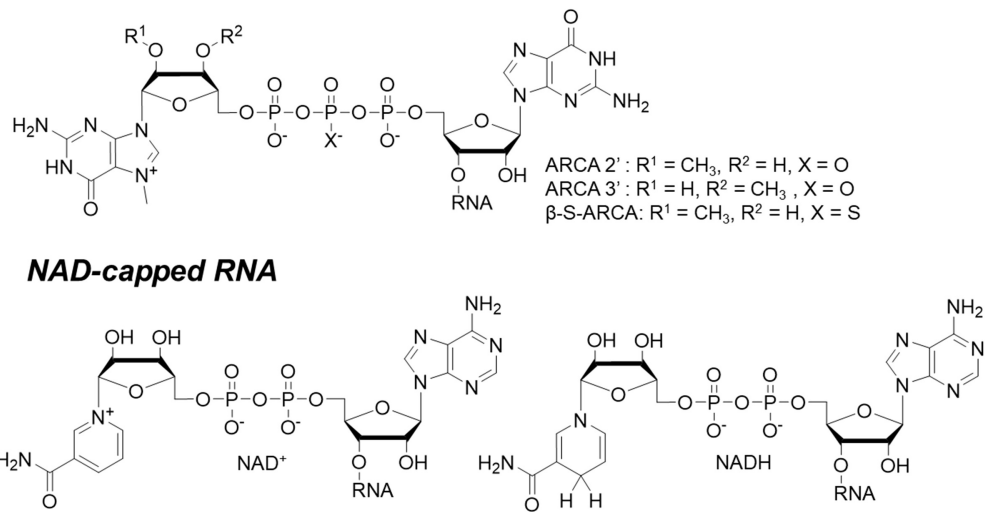

FIGURE 1. RNA $5^{\prime}$-end variants studied in this work.

The presented assay is highly sensitive and allows to bypass the main obstacle in conducting quantitative protein-mRNA interaction experiments, namely the one that limits the amount of transcripts produced by in vitro transcription. We determined binding affinities and obtained the first kinetic data for IFIT1- and IFIT5-RNA interactions. Therefore, we present here a quantitative comparison of a broad range of IFIT ligands that have not been previously coanalyzed, in a single study. Additionally, we demonstrate that some of the atypical caps are recognized by IFIT5 protein with kinetic parameters comparable to the known ligand-pppRNA. Finally, we appraised interactions of IFIT1 with $\mathrm{mRNAs}$ bearing modified cap analogs ARCA and $\beta$-S-ARCA. We hope that these results will provide directions for future improvements of nonimmunogenic RNA for such applications as regenerative medicine or protein replacement.

\section{RESULTS}

\section{Biolayer interferometry allows precise measuring of binding affinities and kinetics of IFIT-RNA interaction}

To characterize the interaction between IFIT proteins and RNAs we used BLI interaction assay and streptavidincoated sensors (Ciesielski et al. 2016). The BLI technique allows analyzing the interference pattern of white light reflected from an internal reference layer and a layer of IFIT proteins immobilized on the biosensor tip and requires only micro volumes of sample for measuring the interaction kinetics. In order to determine the importance of
RNA structural features that influence binding to the IFIT proteins, we prepared a set of mRNAs by in vitro transcription with cotranscriptional or enzymatic capping. Cotranscriptionally capped RNA preparations almost always include a fraction of uncapped pppRNA. To minimize the influence of uncapped fractions, the samples were treated with alkaline phosphatase. Also, the nucleotide sequence was chosen to ensure that produced transcripts are linear. This was to uncouple the effect of cap structure on binding affinity from any additional influence of structural elements present in the $5^{\prime}$ UTR.

The obtained data (Table 1; Fig. 2), demonstrate that IFIT1 interacts with the following ligands: pppA/G16ntRNA， GpppA/G-16ntRNA， $m^{7}$ GpppA/G-16ntRNA and $m^{7}$ GpppAmG-16ntRNA with the $K_{D}$ values in the range of 2.65 to $55.8 \mathrm{nM}$. We did not detect any specific binding of pG-16ntRNA or OH-16ntRNA to IFIT1, which points to a crucial role of the triphosphate chain in ligand association. IFIT1 showed the strongest affinity to unmethylated GpppA/G-16ntRNA ( $K_{D}$ values 2.65 and 5.64 $n M$ for $A$ and $G$, respectively), and $m^{7} G p p p A / G-$ 16ntRNA ( $K_{D}$ values 6.12 and $17.6 \mathrm{nM}$ for $A$ and $G$, respectively) compared to pppA/G-16ntRNA ( $K_{D}$ values 23.4 and $55.8 \mathrm{nM}$ for $A$ and $\mathrm{G}$, respectively), and $\mathrm{m}^{7} \mathrm{GpppAmG}-$ 16ntRNA (44.0 nM). The simple 1:1 binding model fitted to $\mathrm{BLI}$ experimental data showed that $K_{\mathrm{D}}$ variation was mainly related to differences in the kinetic dissociation rate constants, $k_{\mathrm{d}}$. The highest affinity of IFIT1 to GpppG/A-16ntRNA and to $m^{7}$ GpppApG-16ntRNA results from slow dissociation rates $\left(0.137 \times 10^{-3} s^{-1}, 0.176 \times\right.$ $10^{-3} \mathrm{~s}^{-1}$, and $0.106 \times 10^{-3} \mathrm{~s}^{-1}$, respectively) and the highest 
TABLE 1. Binding kinetic parameters of the interaction of IFIT1 or IFIT5 with differently capped mRNAs

\begin{tabular}{|c|c|c|c|c|}
\hline Protein & Ligand-nt16RNA & $K_{\mathrm{D}}(\mathrm{nM})$ & $k_{\mathrm{a}}\left(10^{3} \cdot \mathrm{M}^{-1} \cdot \mathrm{s}^{-1}\right)$ & $k_{d}\left(10^{-3} \cdot s^{-1}\right)$ \\
\hline \multirow[t]{15}{*}{ IFIT1 } & pppG & $55.8 \pm 1.1$ & $32.0 \pm 0.3$ & $1.79 \pm 0.02$ \\
\hline & pppA & $23.4 \pm 0.5$ & $26.0 \pm 0.2$ & $0.607 \pm 0.009$ \\
\hline & GpppG & $5.64 \pm 0.27$ & $24.3 \pm 0.1$ & $0.137 \pm 0.006$ \\
\hline & GpppA & $2.65 \pm 0.11$ & $66.2 \pm 0.4$ & $0.176 \pm 0.006$ \\
\hline & $m^{7} \mathrm{GpppG}$ & $17.6 \pm 0.5$ & $24.8 \pm 0.2$ & $0.436 \pm 0.009$ \\
\hline & $m^{7} G p p p A G$ & $6.12 \pm 0.25$ & $17.2 \pm 0.1$ & $0.107 \pm 0.004$ \\
\hline & $\mathrm{m}^{7} \mathrm{GpppAmG}$ & $44.0 \pm 0.6$ & $35.6 \pm 0.2$ & $1.57 \pm 0.01$ \\
\hline & $\mathrm{m}^{7,2^{\prime}-}$ GpppG (ARCA $\left.2^{\prime}\right)$ & $42.2 \pm 0.5$ & $19.0 \pm 0.1$ & $0.800 \pm 0.005$ \\
\hline & $\mathrm{m}_{2}^{7,3^{\prime}-\mathrm{O}} \mathrm{GpppG}\left(\mathrm{ARCA} 3^{\prime}\right)$ & $69.7 \pm 1.2$ & $22.0 \pm 0.2$ & $1.53 \pm 0.01$ \\
\hline & $\mathrm{m}_{2}{ }^{7,2^{\prime}-\mathrm{O}} \mathrm{GpppG}$ D1 (3-S-ARCA D1) & $31.4 \pm 0.5$ & $35.2 \pm 0.3$ & $1.11 \pm 0.01$ \\
\hline & $\mathrm{m}_{2}{ }^{7,2^{\prime}-\mathrm{O}} \mathrm{GpppG}$ D2 ( $\beta$-S-ARCA D2) & $21.0 \pm 0.8$ & $25.35 \pm 0.1$ & $0.53 \pm 0.005$ \\
\hline & $\mathrm{OH}$ & No interaction & & \\
\hline & $\mathrm{pG}$ & No interaction & & \\
\hline & $\mathrm{NAD}^{+}$ & Weak interaction & & \\
\hline & $\mathrm{NADH}$ & Weak interaction & & \\
\hline \multirow[t]{9}{*}{ IFIT5 } & pG & $78.8 \pm 2.5$ & $9.99 \pm 0.11$ & $0.788 \pm 0.016$ \\
\hline & $\mathrm{ppG}$ & $110 \pm 2$ & $8.44 \pm 0.08$ & $0.930 \pm 0.011$ \\
\hline & pppG & $42.7 \pm 1.6$ & $21.5 \pm 0.37$ & $0.918 \pm 0.019$ \\
\hline & pppG $\left(+\mathrm{Mg}^{2+}\right)$ & $113 \pm 12$ & $8.40 \pm 0.57$ & $0.948 \pm 0.037$ \\
\hline & $\mathrm{NADH}\left(+\mathrm{Mg}^{2+}\right)$ & $46.4 \pm 1.0$ & $16.8 \pm 0.15$ & $0.779 \pm 0.010$ \\
\hline & $\mathrm{NAD}^{+}\left(+\mathrm{Mg}^{2+}\right)$ & $53.7 \pm 0.6$ & $16.3 \pm 0.01$ & $0.875 \pm 0.006$ \\
\hline & GpppG & Weak interaction & & \\
\hline & $m^{7}$ GpppG & Weak interaction & & \\
\hline & $\mathrm{OH}$ & Weak interaction & & \\
\hline
\end{tabular}

Displayed $K_{\mathrm{D}}, k_{\mathrm{d}}$, and $k_{\mathrm{a}}$ values represent the average of three replicate experiments.

stability of the formed complex. On the other hand, $\mathrm{m}^{7}$ GpppAmG-RNA and pppG-RNA binding to IFIT1 is characterized by faster dissociation kinetics $(1.57 \times$ $10^{-3} \mathrm{~s}^{-1}$ and $1.79 \times 10^{-3} \mathrm{~s}^{-1}$, respectively). All interacting ligands showed comparable and moderately fast association rate constants with values ranging from 17.2 to 66.2 $\times 10^{3} \mathrm{M}^{-1} \mathrm{~s}^{-1}$. We also observed that transcripts with an $\mathrm{A}$ at the +1 position showed twofold higher affinity to IFIT1 than transcripts starting with a $\mathrm{G}$.

Using BLI assay, we tested whether IFIT1/RNA interaction is salt dependent. We found that the complex formation was impaired at a concentration of sodium chloride greater than $300 \mathrm{mM}$ (Fig. 3), which further confirmed that association is mostly mediated by electrostatic interactions.

Next, we measured interactions between IFIT5 and differently capped RNAs. We found that IFIT5 is able to bind pppG-16ntRNA, ppG-16ntRNA, and pG-16ntRNA but not GpppG-16ntRNA or $m^{7}$ GpppG-16ntRNA (Table 1; Fig. 4). We also observed IFIT5 interaction with $\mathrm{OH}-$ 16ntRNA, but the response signal was too low to enable high-quality data fitting. Therefore, we interpreted this interaction as a weak binding. From these data we conclude that IFIT5 preferentially interacts with pppG-16ntRNA ligand with $K_{D}$ equal $42.7 \mathrm{nM}$. All of the studied IFIT5/ RNAs complexes displayed moderate association and fast dissociation kinetics. We observed that pppG16ntRNA was a common ligand for both IFIT1 and IFIT5 proteins with comparable affinity for both proteins.
It was reported that IFIT5 neutralizes the negative charge in the RNA-binding pocket arising from Glu33 via a metal ion that bridges the $\alpha$ - and $\gamma$-phosphates of pppG-RNA ligand (Abbas et al. 2013); the authors suggested that either $\mathrm{Mg}^{2+}$ or $\mathrm{Na}^{+}$ions can mediate this interaction. The binding buffer we used in our assays included $\mathrm{Na}^{+}$ions at all times but we also tested IFIT5/RNA interaction upon the addition of $\mathrm{Mg}^{2+}$. As a result, we observed a decreased affinity for IFIT5 protein upon the addition of $\mathrm{Mg}^{2+}$ for both pppG and pG-16ntRNAs (Table 1; Fig. 4).

These results clearly show that both proteins IFIT1 and IFIT5 have specific ligands. IFIT1 strongly binds and forms stable complexes with GpppG/A- and $m^{7}$ GpppG/A-RNAs and contributes to translation inhibition in response to, for example, antiviral program activation. In turn, IFIT5 showed an ability to interact with RNAs bearing three or less phosphates on its $5^{\prime}$ end. However, IFIT5/RNAs complexes were not as stable as in the case of IFIT1. Moreover, IFIT5 showed very similar parameters for a group of interacting ligands with only slight preference for pppG-RNA.

\section{IFIT proteins interact with $\mathrm{NAD}^{+}$and $\mathrm{NADH}$ containing transcripts}

Recently it has been reported that bacterial RNAs can carry the nucleotide-containing metabolite $\mathrm{NAD}^{+}$at the $5^{\prime}$ end (Cahová et al. 2015; Jäschke et al. 2016). Later it was also shown that $\mathrm{NAD}^{+}$-capping exists in eukaryotes and 

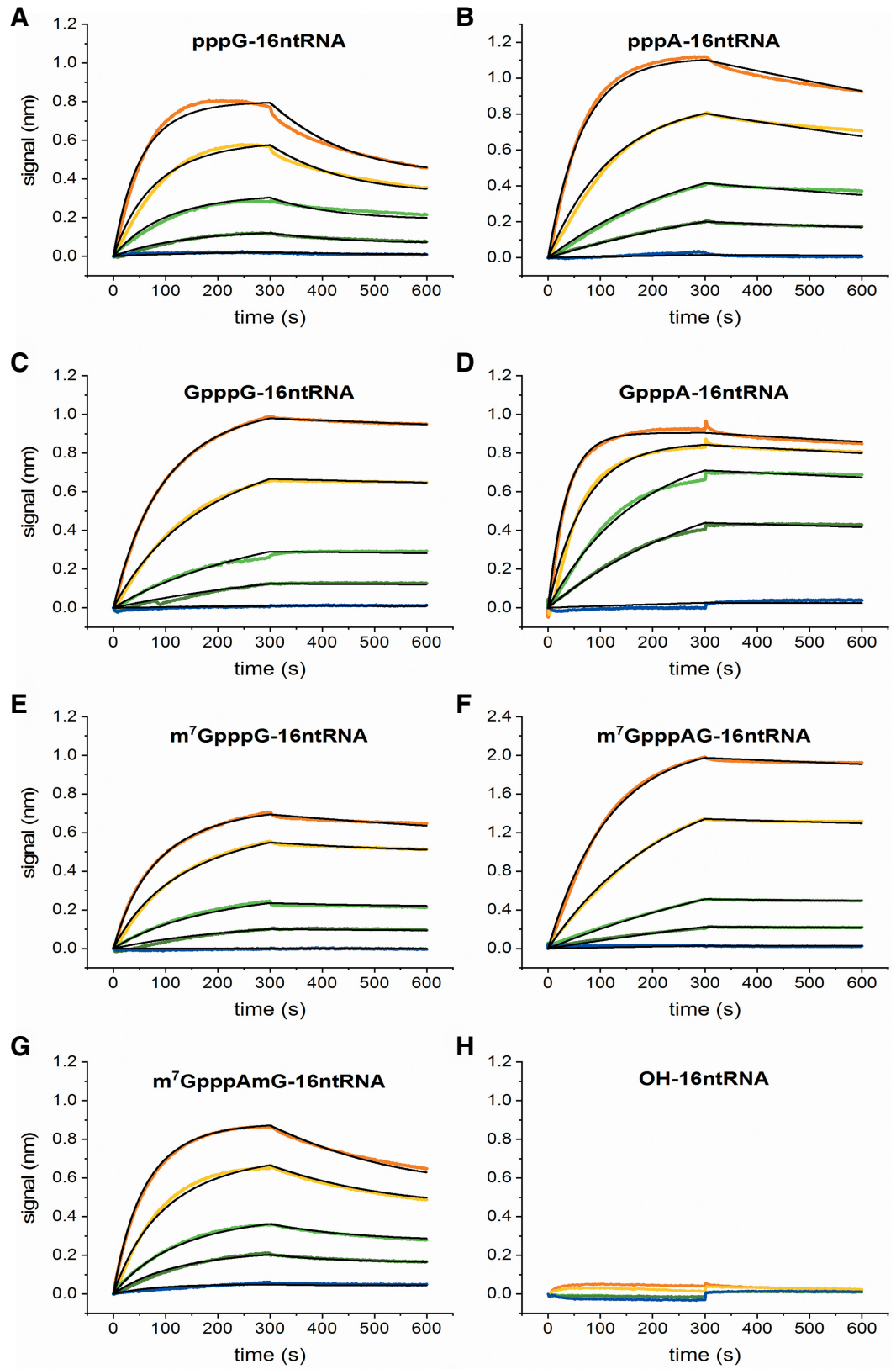

H
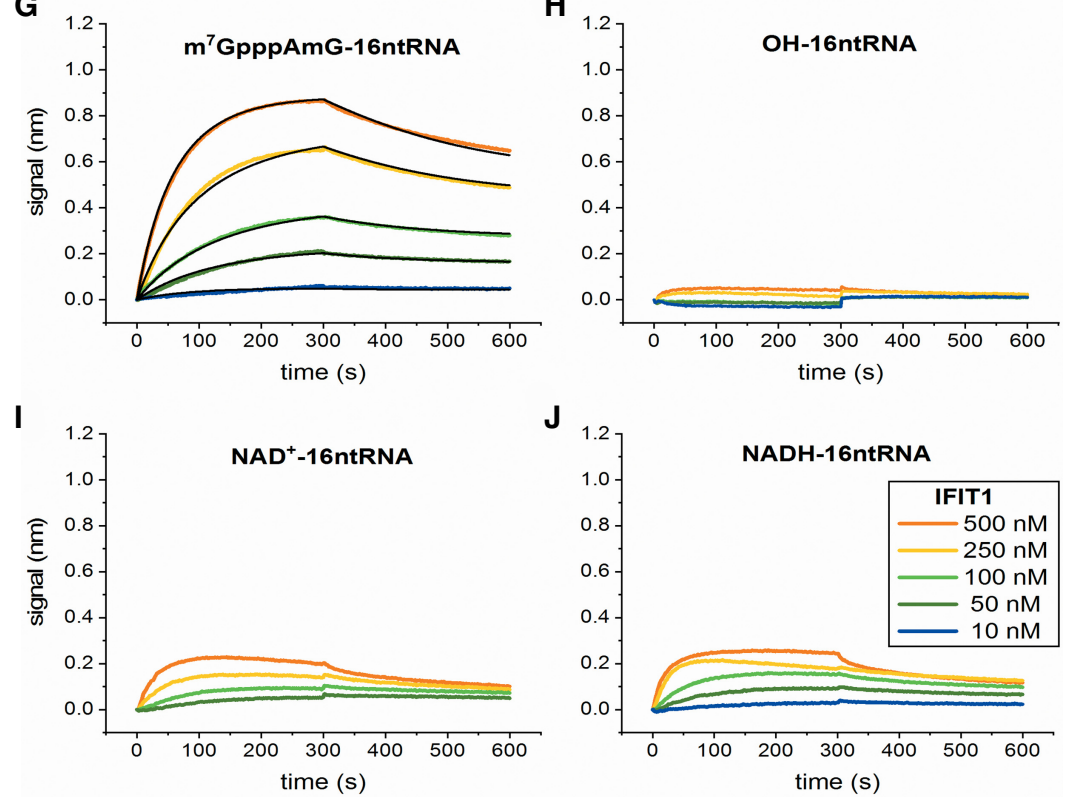

FIGURE 2. BLI analyses of IFIT1 interaction with immobilized differently capped short RNAs. Biotinylated RNAs bearing on $5^{\prime}$ end $(A)$ pppG, (B) pppA, (C) GpppG, (D) GpppA, (E) $\mathrm{m}^{7} \mathrm{GpppG},(F) \mathrm{m}^{7} \mathrm{GpppAG},(G) \mathrm{m}^{7} \mathrm{GpppAmG},(H) \mathrm{OH},(I) \mathrm{NAD}^{+}$, and $(J) \mathrm{NADH}$ were immobilized on streptavidin sensors and allowed to interact with increasing concentrations of IFIT1 (2-500 nM). The simple 1:1 binding model (black lines) was fitted to BLI data traces (differently colored lines) and plotted as the spectral nanometer shift as a function of time. was detected in Saccharomyces cerevisiae (Walters et al. 2017) and human mRNAs (Jiao et al. 2017). In contrast to $\mathrm{m}^{7} \mathrm{G}, \mathrm{NAD}^{+}$cap in eukaryotes does not promote stability and translation, but instead it promotes rapid mRNA degradation (Jiao et al. 2017). We thus tested whether such transcripts can be recognized by IFIT proteins. The obtained BLI data revealed very weak and unstable interaction between $\mathrm{NAD}^{+}$or NADH-RNA and IFIT1 (Fig. 2). On the other hand, these RNAs were readily recognized by IFIT5. In particular, NADH16ntRNA associated with IFIT5 with kinetic parameters comparable with pppG-16ntRNA (Table 1; Fig. 4). However, in contrast to pppG16ntRNA, both $\mathrm{NAD}^{+}$- and $\mathrm{NADH}-$ 16ntRNAs favored binding to IFIT5 in the presence of magnesium ions.

\section{ARCA and $\beta$-S-ARCA modification of cap structure protects mRNA from IFIT1-mediated translation inhibition}

Both ARCA and $\beta$-S-ARCA have found application in biotechnology and in mRNA-based experimental therapeutic inventions. $\beta$-S-ARCA capped RNA have already been used as RNAbased cancer vaccines in preclinical and clinical trials. However, the data on the potential of these cap analogs to induce cellular immune responses and the possibility to interact with the expressed proteins is limited. Thus we tested interaction of IFIT1 with IVT mRNA capped with ARCA (Stepinski et al. 2001; Jemielity et al. 2003) and $\beta$-S-ARCA (GrudzienNogalska et al. 2007; Kuhn et al. 2010).

Our results indicate that the modification of either $2^{\prime}-\mathrm{OH}$ or $3^{\prime}-\mathrm{OH}$ of the $\mathrm{m}^{7} \mathrm{G}$ ribose with methyl group decreases the stability of the ARCA16ntRNA/IFIT1 complex two- to threefold compared to the $m^{7} G p p p G-$ 16ntRNA/IFIT1, while modification of the $3^{\prime}$ group provided an even stronger effect (Table 1; Fig. 5). The phosphorothioate modification in the 


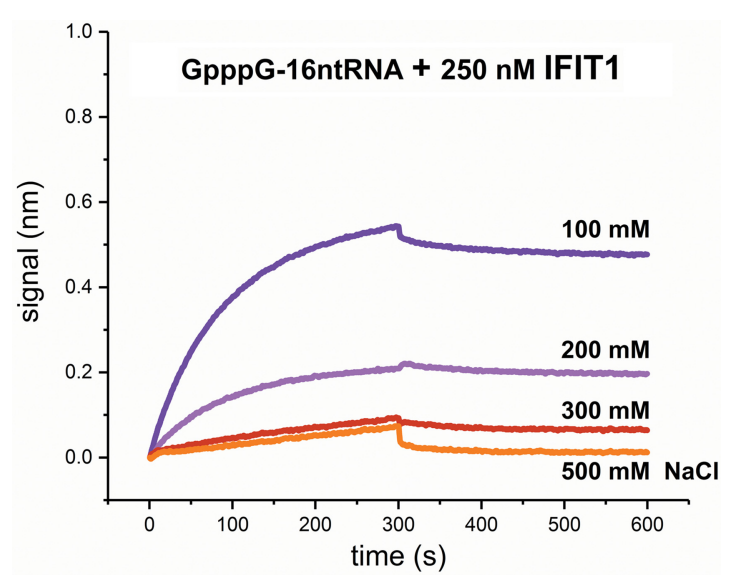

FIGURE 3. IFIT1-GpppG-16ntRNA interaction depending on $\mathrm{NaCl}$ concentration. Biotinylated GpppG-16ntRNA was immobilized on streptavidin sensors and allowed to interact with $250 \mathrm{nM}$ IFIT1 in the kinetic buffer containing different concentrations of $\mathrm{NaCl}(100$ $500 \mathrm{mM}$ ). BLI data traces (differently colored lines) were plotted as the spectral nanometer shift as a function of time.

triphosphate chain of $\beta$-S-ARCA D1 slightly weakened the dissociation rate $k_{d}$ of the complex $\left(0.800 \times 10^{-3} \mathrm{~s}^{-1}\right.$ for $\mathrm{m}_{2}{ }^{7,2^{\prime}-\mathrm{O}} \mathrm{GpppG}$ compared to $1.11 \times 10^{-3} \mathrm{~s}^{-1}$ for $\beta$-S-ARCA D1) but did not increase significantly the general affinity of the RNA ligands to the IFIT1 protein. In contrast, $\beta$-SARCA D2-capped RNA was characterized with an increased dissociation rate of the complex when compared to $\mathrm{m}_{2}{ }^{7,2^{\prime}-O} \mathrm{GpppG}$-capped RNA. These results reveal that ARCA and stereoisomer D1 of $\beta$-S-ARCA can protect, to some extent, capped mRNA from binding to IFIT1 protein. This, in turn, allows for efficient protein expression from introduced engineered IVT mRNA even if it was recognized as nonself by the cell (Kuhn et al. 2010).

\section{DISCUSSION}

Several reports showed that the mRNA lacking crucial modifications at its $5^{\prime}$ end is a target of interferon-induced proteins with tetratricopeptide IFIT1 and IFIT5. Even though certain studies determined the initial scope of substrates for both proteins, the published data on binding specificities of individual protein/ligand pairs is incomplete. Furthermore, although already established biochemical assays allow approximate determination of apparent $K_{D}$, they do not give insights into the kinetics of IFITs/RNA interactions. Here we performed for the first time kinetic characterization of IFIT1 and IFIT5 interactions with a spectrum of RNA ligands using BLI assay. Our results show that IFIT1/RNA association is highly dependent on the presence of the triphosphate chain on the $5^{\prime}$ end of RNA while the presence of neither terminal $G$ residue nor 2'-O-methylation on the ribose residue of the first nucleotide adjacent to the $m^{7} G$ cap significantly influences the kinetics of the association with the protein. The crystal structure of IFIT1 bound to pppRNA reported by Abbas et al. (2017) showed that PPP moiety is held by numerous specific electrostatic interactions formed with the protein side chains (Fig. 6). Our data indicate that this positively charged surface inside the IFIT1 RNA-binding tunnel most likely plays an important role in the initial electrostatic recognition of the ligand. This is supported by the observation that addition of sodium chloride in a concentration above $300 \mathrm{mM}$ significantly reduces IFIT1/RNA complex formation.

Data obtained from BLI experiments showed that IFIT1 creates very stable complexes with RNA. The very long residence time of IFIT1 on RNA would suggest that a large number of molecules is necessary to inhibit viral infection. Indeed, it has been shown that detection of foreign RNA causes high expression of IFIT1 gene in infected and neighboring cells preparing them for the fight against the virus (Sarkar and Sen 2004; Hartmann 2017).

Then we observed significant differences in the stability of IFIT1 complexes with differently capped RNAs. The most stable complex was between IFIT1 and RNA bearing GpppG/A or m7GpppG/A on its $5^{\prime}$ end. We observed some differences in the stability of complexes of IFIT1 with transcripts containing $A$ or $G$ at position $N^{1}$. This phenomenon requires further studies since $N^{1}$ adenine can be further methylated to form $N^{6}, 2^{\prime}$-O-dimethyladenosine $\left(m^{6} \mathrm{Am}\right)$. Transcripts containing such a modification were shown to preferentially induce translation and have an enhanced stability due to the resistance to decapping by Dcp2, a crucial enzyme engaged in mRNA degradation (Mauer et al. 2016). Whether this modification affects IFIT1 binding remains to be elucidated.

Our discovery that the most stable complex was formed between IFIT1 and GpppG/A-16ntRNA is particularly surprising considering that, to the best of our knowledge, there are no viruses utilizing GpppG-RNAs. One possible explanation is that IFIT1 might have an ability to target transient intermediates formed during viral mRNA capping. On the other hand, IFIT1 might also play a role in a surveillance mechanism preventing expression of aberrantly capped mRNAs. It was reported that some of the pre-mRNAs escape the nucleus without being spliced and reach the cytoplasm where they are targeted to nonsense-mediated decay (NMD) to limit their translation (Bonde et al. 2014). This hypothesis is supported by the analysis of IFIT1 protein interaction network which revealed a large group of proteins involved in RNA processing, including SNRPA, SNRPC, SNRPE, and HNRNPs (Pichlmair et al. 2011). It has also been suggested that immature or aberrantly processed tRNAs can constitute valid substrates for IFIT5 protein (Katibah et al. 2014). Also, considering that the canonical cap methyltransferase has been shown to be present and active in the cytoplasm, it is possible for GpppG-RNA to be $N^{7}$ methylated and included into a translationally active pool of transcripts 

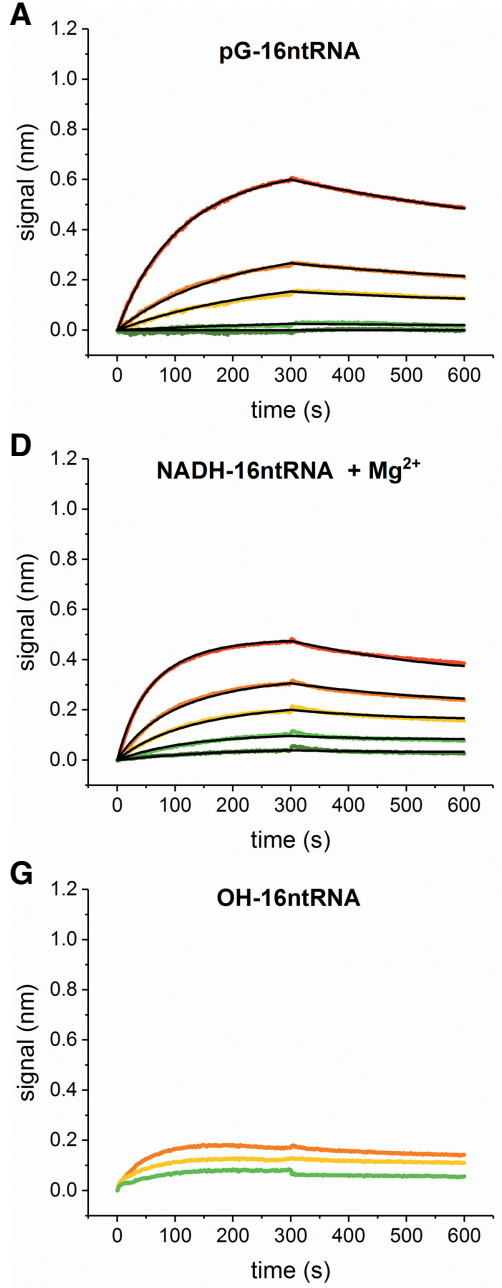

B

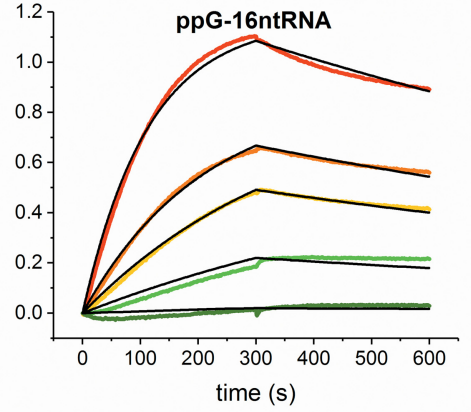

E

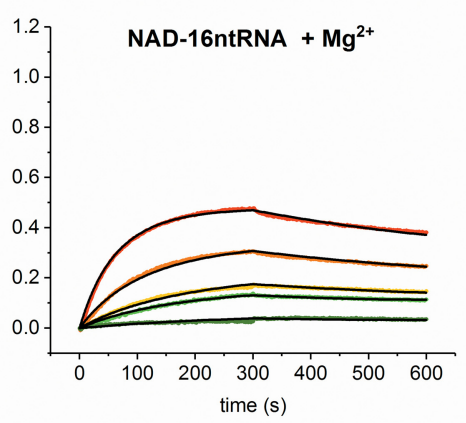

H

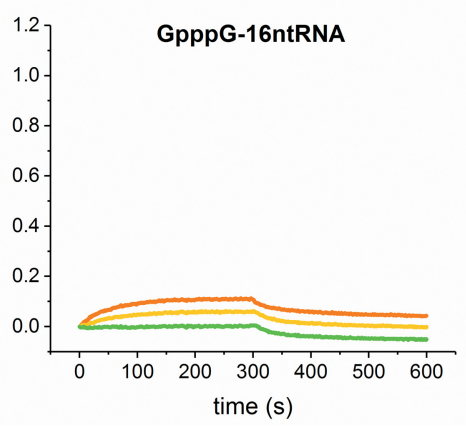

C

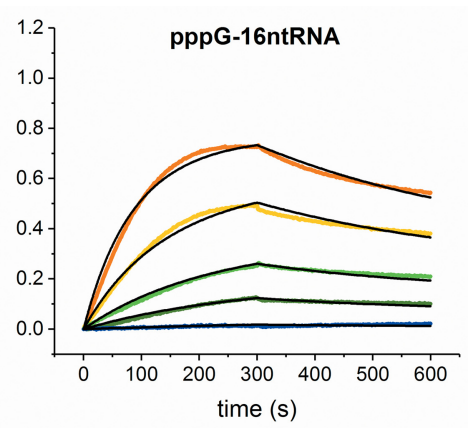

$\mathbf{F}$

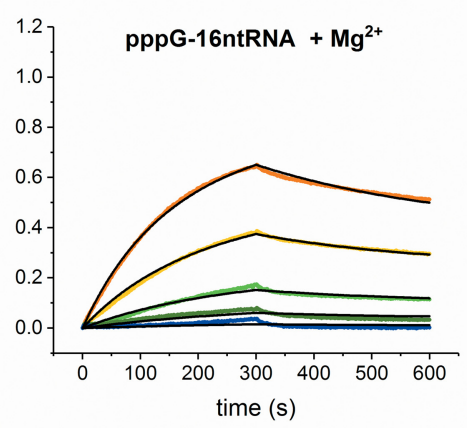

I

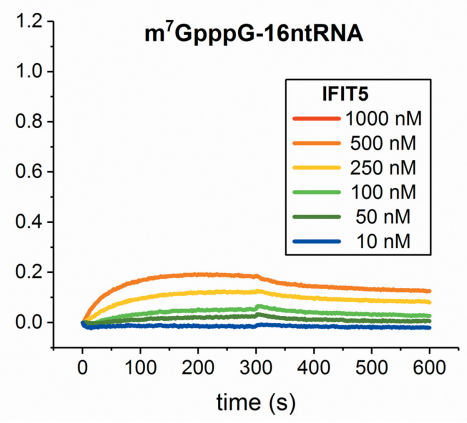

FIGURE 4. BLI analyses of IFIT5 interaction with immobilized differently capped short RNAs. Biotinylated RNAs bearing on $5^{\prime}$ end (A) pG, $(B)$ ppG, (C) pppG, (G) OH, (H) GpppG, (I) $\mathrm{m}^{7} \mathrm{GpppG},(D) \mathrm{NADH}_{1}(E) \mathrm{NAD}^{+}$, and (F) pppG in the presence of $\mathrm{Mg}^{2+}$ were immobilized on streptavidin sensors and allowed to interact with increasing concentrations of IFIT5 (2-1000 nM). The simple 1:1 binding model (black lines) was fitted to BLI data traces (differently colored lines) and plotted as the spectral nanometer shift as a function of time.

(Trotman et al. 2017). This in turn suggests that it would be beneficial for the cell to block such aberrant mRNA transcripts by specialized factors.

Subsequently, we have performed kinetic studies on IFIT5 interactions with a range of mRNA ligands. We found that IFIT5 preferentially binds pppG-16ntRNA—the common ligand for IFIT5 and IFIT1. Comparing kinetic parameters of pppG-16ntRNA binding to IFIT1 and IFIT5 proteins, we observed slightly stronger affinity for IFIT5 protein. However, the stability of the complex was noticeably lower than the best pair of IFIT1/GpppG-16ntRNA. This prompted us to widen the scope of tested ligands and binding conditions. We tested for both IFIT1 and IFIT5 interactions with $\mathrm{NAD}^{+}$and $\mathrm{NADH}-16$ ntRNAs. IFIT1 showed a very weak affinity for either of these ligands and formed only unstable complexes. However, IFIT5 interacted relatively strongly especially with $\mathrm{NADH}-$ 16ntRNA. The determined kinetic constants were compa- rable with pppG-16ntRNA. Additionally, in contrast to pppG and pG-16ntRNAs, higher affinity was observed when the binding buffer was supplemented with $\mathrm{Mg}^{2+}$ ions. Nevertheless, as we only begin to unravel the metabolism of RNAs bearing alternative cap structures at the $5^{\prime}$ terminus, it is very difficult to answer the question about NADH/IFIT5 biological significance.

Last but not least, we tested IFIT1 for binding to the ARCA and $\beta$-S-ARCA capped RNAs. Both cap analogs show increased affinity toward eukaryotic translation initiation factor $4 \mathrm{E}$ compared to the canonical cap structure. $\beta$ S-ARCA additionally protects mRNA against the hydrolytic activity of decapping enzyme Dcp2. Here, we found that particularly ARCA $3^{\prime}$ and $\beta$-S-ARCA D1 cap analogs restricted the formation of a stable complex between IFIT1 and ARCAs capped RNA. They protected RNA from IFIT1 binding on a similar level to that of cap 1. This particular property can be very beneficial for the design of 

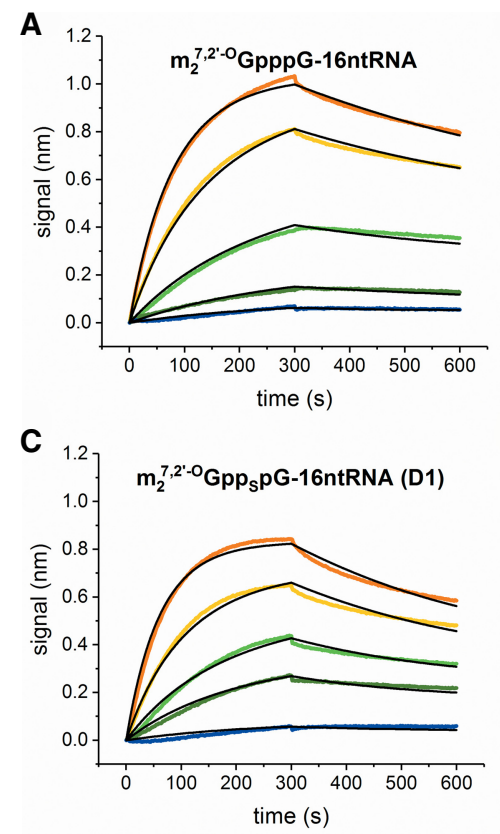

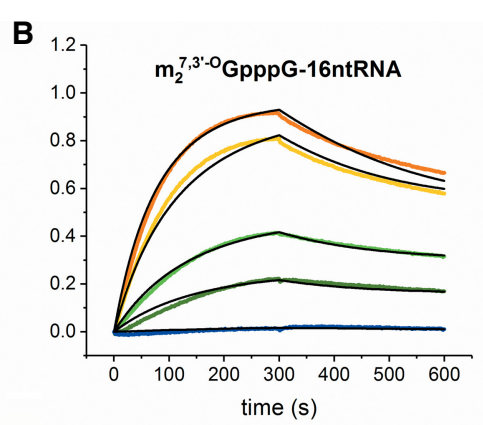

D

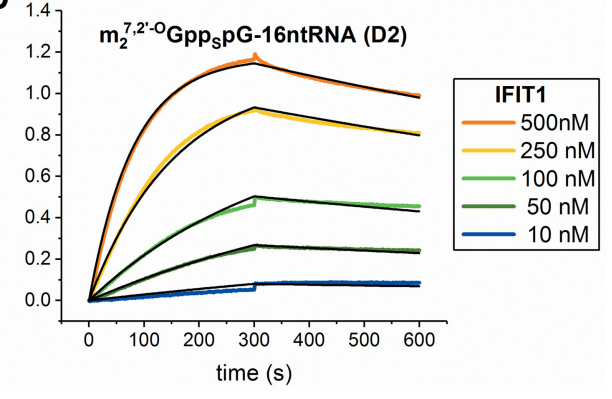

FIGURE 5. BLI analyses of IFIT1 interaction with immobilized short RNAs capped with modified cap analogs. Biotinylated RNAs bearing on $5^{\prime}$ end $(A) m_{2}{ }^{7,2^{\prime}-O} G p p p G,(B) m_{2}{ }^{7,3^{\prime}-O} G p p p G$, (C) $\mathrm{m}_{2}{ }^{7,2^{\prime}-\mathrm{O}} \mathrm{GppspG}$ (D1), (D) $\mathrm{m}_{2}{ }^{7,2^{\prime}-\mathrm{O}} \mathrm{GppspG}$ (D2) were immobilized on streptavidin sensors and allowed to interact with increasing concentrations of IFIT1 $(2-500 \mathrm{nM})$. The simple 1:1 binding model (black lines) was fitted to BLI data traces (differently colored lines) and plotted as the spectral nanometer shift as a function of time.

mRNA-based vaccines. During the last several years, mRNAs have been investigated extensively as a potential therapeutic platform. However, such vaccines possess inherent RNA immunogenicity inasmuch as they activate innate immune response. Our findings show that $\beta$-S-ARCA prevents binding of the transcript by IFIT1 protein. This effect may contribute to the favorable properties of $\beta$-SARCA capped mRNA vaccines and can be beneficial for the efficacy of other mRNA-based therapeutics.

\section{MATERIALS AND METHODS}

\section{Cap analogs}

GpppG and ApppG were synthesized as previously described (Darzynkiewicz et al. 1990; Stepinski et al. 1995). $\mathrm{m}^{7}$ GpppAmG was purchased from Trilink Biotechnologies. NAD ${ }^{+}$and NADH were purchased from Roche and Roth, respectively. Synthesis of $\mathrm{m}_{2}{ }^{7,3^{\prime}-} \mathrm{GpppG}$ was described in Stepinski et al. (2001) and $\mathrm{m}_{2}{ }^{7,2^{\prime}-\mathrm{O}} \mathrm{GpppG}, \beta$-S-ARCA D1, and $\beta$-S-ARCA D2 in Kowalska et al. (2008). $m^{7} G p p p A G$ was synthesized from $p A p G$ and $\mathrm{m}^{7}$ GDP-Im as follows: pApG (3.4 mg, $\left.4.65 \mu \mathrm{mol}\right)$ was dissolved in DMSO $(100 \mu \mathrm{L})$ followed by addition of $\mathrm{m}^{7} \mathrm{GDP}-\mathrm{Im}(12.8 \mathrm{mg}$, $23.2 \mu \mathrm{mol})$ and $\mathrm{ZnCl}_{2}(25.3 \mathrm{mg}, 186 \mu \mathrm{mol})$. After $24 \mathrm{~h}$ the reaction was quenched by dilution with aqueous solution $(3.5 \mathrm{~mL}$ ) of EDTA (69 mg, $186 \mu \mathrm{mol}$ ) and $\mathrm{NaHCO}_{3}(35 \mathrm{mg}, 411 \mu \mathrm{mol}$ ) and chromatographed on DEAE Sephadex. The product was additionally purified by RP HPLC to give, after concentration and repeated freeze-drying from water, ammonium salt of $\mathrm{m}^{7} \mathrm{GpppApG}$
(2.2 mg, $1.85 \mu \mathrm{mol}$ ) in $40 \%$ yield. The PApG dinucleotide was obtained by a phosphoramidite approach in solid phase on PrimerSupport 5G (GE Healthcare) and isolated as a triethylammonium salt by ion-exchange chromatography on DEAE Sephadex; $\mathrm{m}^{7} \mathrm{GDP}$-Im was synthesized as described earlier (Kowalska et al. 2008).

\section{Protein expression and purification}

pET28a(+) 6xHis-TEV-IFIT1 and pET28a(+) 6xHis-TEV-IFIT5 were a gift from Kathleen Collins (Addgene plasmids \# 53557 and \# 53560) (Katibah et al. 2013). IFIT proteins were expressed in BL21(DE3), induced with $0.2 \mathrm{mM}$ IPTG and grown overnight at $22^{\circ} \mathrm{C}$. The cell pellets were resuspended in buffer A containing $50 \mathrm{mM}$ sodium phosphate $\mathrm{pH} 7.2,400 \mathrm{mM} \mathrm{NaCl}, 20 \mathrm{mM}$ imidazole, $0.5 \mathrm{mM}$ DTT and cOmplete Protease Inhibitor Cocktail (Roche), lysed by sonication and centrifuged. The soluble fraction was applied on a Ni-NTA HiTrap column (GE Healthcare) equilibrated in the same buffer. Unbound proteins were washed away using $130 \mathrm{mM}$ imidazole in buffer A. IFIT proteins were eluted from the column with buffer A containing $600 \mathrm{mM}$ imidazole. Imidazole was removed by applying protein fractions on PD-10 Desalting Columns. Finally, proteins were stored in $50 \mathrm{mM}$ sodium phosphate, $150 \mathrm{mM} \mathrm{NaCl}, 0.5 \mathrm{mM} \mathrm{DTT}$, and 10\% glycer$\mathrm{ol}$, flash frozen in liquid nitrogen, and kept at $-80^{\circ} \mathrm{C}$ until use.

\section{RNA preparation}

Short 16nt RNA of (G/A)GGAGACCGGCCTCGA sequence were prepared as described previously (Grzela et al. 2018). 5' triphosphate 16ntRNA (pppG/pppA-16ntRNA) were synthesized by IVT using $1 \mathrm{U} / \mu \mathrm{L}$ T7 RNA Polymerase (Thermo), $5 \mathrm{ng} / \mu \mathrm{L}$ of Xhol linearized pSPluc+ plasmid template containing either T7 class III promoter $\varphi 6.5$ or T7 class II promoter $\varphi 2.5,0.5 \mathrm{mM}$ ATP, GTP, CTP, UTP, and 1U/RiboLock RNase Inhibitor (Thermo). GpppG/A-, $m^{7}$ GpppAG-, $m^{7}$ GpppAmG-, $m_{2}^{7,2^{\prime}-O}$ GpppG-, m2 ${ }^{7,3^{\prime}-O}$ GpppG-, $\beta$-S-ARCA D1-, $\beta$-S-ARCA D2-, NAD ${ }_{-}^{+}$, and NADH-capped 16ntRNAs were obtained by cotranscriptional capping using 0.5 mM GpppG/A, m7pppAG, m7 GpppAmG (CleanCap Reagent $A G$, Trilink Biotechnologies), $m_{2}{ }^{7,2^{\prime}-O} \mathrm{GpppG}, \mathrm{m}_{2}{ }^{7,3^{\prime}-O} \mathrm{GpppG}, \beta-$ S-ARCA D1, $\beta$-S-ARCA D2, NAD ${ }^{+}$(Roche) or NADH (Roth) di- or trinucleotides and $0.1 \mathrm{mM}$ GTP/ATP. $\mathrm{m}^{7}$ GpppG-16ntRNA was prepared by enzymatic capping with the ScriptCap $m^{7} G$ Capping System (CellScript) according to the manufacturer's instructions. 5' $\mathrm{OH}-16$ ntRNA was prepared by ppp16ntRNA treatment with alkaline phosphatase (Thermo) for $10 \mathrm{~min}$ at $37^{\circ} \mathrm{C}$. p16ntRNA was prepared by ppp16ntRNA treatment with RNA $5^{\prime}$ polyphosphatase (Epicentre) for $1 \mathrm{~h}$ at $37^{\circ} \mathrm{C}$. pp $16 n t R N A$ was prepared by enzymatic capping with ScriptCap $\mathrm{m}^{7} \mathrm{G}$ Capping System (CellScript) without addition of GTP and AdoMet. After 


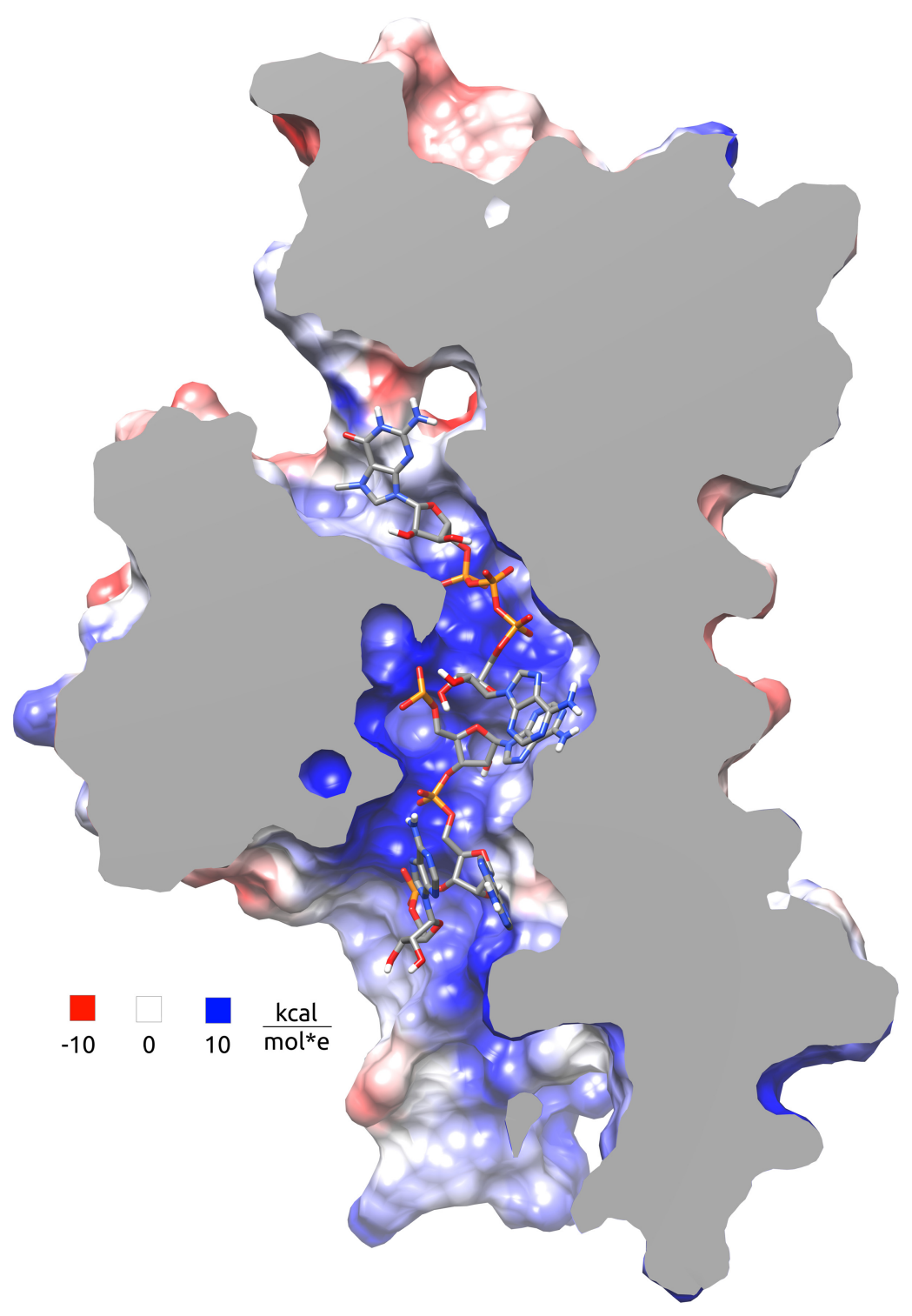

FIGURE 6. Cross-section of IFIT1 (PDB ID 5UDL) in the complex with capped mRNA. Protein surface is colored according to the electrostatic potential calculated with Chimera based on Coulomb's law.

transcription all RNAs, except pppG/A-16ntRNA, were treated with alkaline phosphatase to remove any remaining phosphate groups from RNA. Finally, RNAs were purified using Oligo Clean-up and Concentration Kit (Norgen Biotek) and analyzed by denaturing PAGE on a 15\% polyacrylamide/7 M urea gel (Supplemental Fig. S1). All studied RNA 5'-end variants were presented in Figure 1.

\section{Biolayer interferometry (BLI) assay}

The BLItz system (Pall ForteBio) was used for BLI interaction assays. Short RNAs obtained by IVT as described above were biotinylated using Pierce RNA 3' End Biotinylation Kit according to the manufacturer's instructions (Thermo). Short biotin-labeled RNAs containing different $5^{\prime}$ ends were immobilized onto streptavidin-coated biosensors (Pall ForteBio) by immersing the sensor in $1 \mu \mathrm{M}$ RNA solution in kinetic buffer (50 $\mathrm{mM}$ phosphate buffer $\mathrm{pH} 7.2$, containing $150 \mathrm{mM} \mathrm{NaCl}, 10 \%$ glycerol, $0.5 \mathrm{mM}$ DTT, $0.1 \%$ BSA, and $0.05 \%$ Tween 20 ) for 5 min with $1000 \mathrm{rpm}$ shaking. To minimize nonspecific interactions the sensor was blocked with $10 \mu \mathrm{g} / \mathrm{mL}$ EZ-LINK Biocytin (Thermo) and washed with kinetic buffer. The association of the proteins was measured by incubating RNA immobilized sensors in various concentrations of IFIT1 or IFIT5 proteins (2-1000 nM) diluted in kinetic buffer. The dissociation constants were measured by transferring the biosensor from protein solution to kinetic buffer and incubated for $5 \mathrm{~min}$. The ForteBio analysis software was used to fit and analyze the data. The mean values of equilibrium dissociation constant $K_{\mathrm{D}}$, and kinetic association and dissociation rates $k_{\mathrm{a}}$ and $k_{d}$ were calculated from three independent experiments.

\section{SUPPLEMENTAL MATERIAL}

Supplemental material is available for this article.

\section{ACKNOWLEDGMENTS}

pET28a(+) 6xHis-TEV-IFIT1 and pET28a(+) $6 x$ His-TEV-IFIT5 were a gift from Kathleen Collins (University of California) (Addgene plasmids \#53557 and \#53560). We thank Zbigniew Darzynkiewicz (New York Medical College), Aurelie Rakotondrafara (University of Wisconsin-Madison), and Anna Stankiewicz-Drogon (University of Warsaw) for reading the manuscripts and Sonja Lukic (PALL ForteBio) for helpful discussions. This work was supported by the Polish National Science Centre (UMO/2013/08/A/NZ1/00866 to E.D. and NCN ETIUDA 2017/24/T/NZ1/00345 to M.W.); National Centre of Research and Development (STRATEGMED1/235773/ 19/NCBR/2016 to E.D.); and the Foundation for Polish Science (TEAM/2016-2/13 to J.J.).

Received September 23, 2019; accepted October 24, 2019.

\section{REFERENCES}

Abbas YM, Pichlmair A, Górna MW, Superti-Furga G, Nagar B. 2013. Structural basis for viral 5'-PPP-RNA recognition by human IFIT proteins. Nature 494: 60-64. doi:10.1038/nature11783

Abbas YM, Laudenbach BT, Martínez-Montero S, Cencic R, Habjan M, Pichlmair A, Damha MJ, Pelletier J, Nagar B. 2017. Structure of 
human IFIT1 with capped RNA reveals adaptable mRNA binding and mechanisms for sensing $\mathrm{N} 1$ and $\mathrm{N} 2$ ribose 2'-O methylations. Proc Natl Acad Sci 114: E2106-E2115. doi:10.1073/pnas .1612444114

Bélanger F, Stepinski J, Darzynkiewicz E, Pelletier J. 2010. Characterization of hMTr1, a human Cap1 2'-O-ribose methyltransferase. J Biol Chem 285: 33037-33044. doi:10.1074/jbc .M110.155283

Bird JG, Basu U, Kuster D, Ramachandran A, Grudzien-Nogalska E, Towheed A, Wallace DC, Kiledjian M, Temiakov D, Patel SS, et al. 2018. Highly efficient $5^{\prime}$ capping of mitochondrial RNA with $\mathrm{NAD}^{+}$and NADH by yeast and human mitochondrial RNA polymerase. Elife 7: e42179. doi:10.7554/eLife.42179

Bonde MM, Voegeli S, Baudrimont A, Séraphin B, Becskei A. 2014. Quantification of pre-mRNA escape rate and synergy in splicing. Nucleic Acids Res 42: 12847-12860. doi:10.1093/nar/gku1014

Cahová H, Winz ML, Höfer K, Nübel G, Jäschke A. 2015. NAD captureSeq indicates NAD as a bacterial cap for a subset of regulatory RNAs. Nature 519: 374-377. doi:10.1038/nature14020

Ciesielski GL, Hytönen VP, Kaguni LS. 2016. Biolayer interferometry: a novel method to elucidate protein-protein and protein-DNA interactions in the mitochondrial DNA replisome. Methods Mol Biol 1351: 223-231. doi:10.1007/978-1-4939-3040-1_17

Daffis S, Szretter KJ, Schriewer J, Li J, Youn S, Errett J, Lin T-Y, Schneller S, Zust R, Dong H, et al. 2010. 2'-O methylation of the viral mRNA cap evades host restriction by IFIT family members. Nature 468: 452-456. doi:10.1038/nature09489

Darzynkiewicz E, Stepinski J, Tahara SM, Stolarski R, Ekiel I, Haber D, Neuvonen K, Lehikoinen P, Labadi I, Lonnberg H. 1990. Synthesis, conformation and hydrolytic stability of $\mathrm{p}^{1}, \mathrm{p}^{3}$-dinucleoside triphosphates related to mRNA 5'-cap, and comparative kinetic studies on their nucleoside and nucleoside monophosphate analogs. Nucleosides Nucleotides 9: 599-618. doi:10.1080/ 07328319008045191

Devoldere J, Dewitte H, De Smedt SC, Remaut K. 2016. Evading innate immunity in nonviral mRNA delivery: don't shoot the messenger. Drug Discov Today 21: 11-25. doi:10.016/j.drudis.2015.07 .009

Feng F, Yuan L, Wang YE, Crowley C, Lv Z, Li J, Liu Y, Cheng G, Zeng S, Liang H. 2013. Crystal structure and nucleotide selectivity of human IFIT5/ISG58. Cell Res 23: 1055-1058. doi:10.1038/cr .2013 .80

Grudzien-Nogalska E, Jemielity J, Kowalska J, Darzynkiewicz E, Rhoads RE. 2007. Phosphorothioate cap analogs stabilize mRNA and increase translational efficiency in mammalian cells. RNA 13: 1745-1755. doi:10.126/rna.701307

Grzela R, Nasilowska K, Lukaszewicz M, Tyras M, Stepinski J, Jankowska-Anyszka M, Bojarska E, Darzynkiewicz E. 2018. Hydrolytic activity of human Nudt16 enzyme on dinucleotide cap analogs and short capped oligonucleotides. RNA 24: 633642. doi:10.1261/rna.065698.118

Habjan M, Hubel P, Lacerda L, Benda C, Holze C, Eberl CH, Mann A, Kindler E, Gil-Cruz C, Ziebuhr J, et al. 2013. Sequestration by IFIT1 impairs translation of 2'O-unmethylated capped RNA. PLoS Pathog 9: 1003663. doi:10.1371/journal.ppat.1003663

Hartmann G. 2017. Nucleic acid immunity. Adv Immunol 133: $121-$ 169. doi: $10.1016 /$ bs.ai.2016.11.001

Jäschke A, Höfer K, Nübel G, Frindert J. 2016. Cap-like structures in bacterial RNA and epitranscriptomic modification. Curr Opin Microbiol 30: 44-49. doi:10.1016/j.mib.2015.12.009

Jemielity J, Fowler T, Zuberek J, Stepinski J, Lewdorowicz M, Niedzwiecka A, Stolarski R, Darzynkiewicz E, Rhoads RE. 2003. Novel "anti-reverse" cap analogs with superior translational properties. RNA 9: 1108-1122. doi:10.1261/rna.5430403
Jiao X, Doamekpor SK, Bird JG, Nickels BE, Tong L, Hart RP, Kiledjian M. 2017. $5^{\prime}$ end nicotinamide adenine dinucleotide cap in human cells promotes RNA decay through DXO-mediated deNADding. Cell 168: 1015-1027. doi:10.1016/j.cell.2017.02 .019

Katibah GE, Lee HJ, Huizar JP, Vogan JM, Alber T, Collins K. 2013. TRNA binding, structure, and localization of the human interferon-induced protein IFIT5. Mol Cell 49: 743-750. doi:10.1016/j .molcel.2012.12.015

Katibah GE, Qin Y, Sidote DJ, Yao J, Lambowitz AM, Collins K. 2014. Broad and adaptable RNA structure recognition by the human interferon-induced tetratricopeptide repeat protein IFIT5. Proc Natl Acad Sci 111: 12025-12030. doi:10.1073/pnas.1412842111

Kimura T, Katoh H, Kayama H, Saiga H, Okuyama M, Okamoto T, Umemoto E, Matsuura Y, Yamamoto M, Takeda K. 2013. Ifit1 inhibits Japanese encephalitis virus replication through binding to 5' capped 2'-O unmethylated RNA. J Virol 87: 9997-10003. doi:10.1128/JVI.00883-13

Kowalska J, Lewdorowicz M, Zuberek J, Grudzien-Nogalska E, Bojarska E, Stepinski J, Rhoads RE, Darzynkiewicz E, Davis RE, Jemielity J. 2008. Synthesis and characterization of mRNA cap analogs containing phosphorothioate substitutions that bind tightly to elF4E and are resistant to the decapping pyrophosphatase DcpS. RNA 14: 1119-1131. doi:10.1261/rna.990208

Kowtoniuk WE, Shen Y, Heemstra JM, Agarwal I, Liu DR. 2009. A chemical screen for biological small molecule-RNA conjugates reveals CoA-linked RNA. Proc Natl Acad Sci 106: 7768-7773. doi:10 .1073/pnas.0900528106

Kuhn AN, Diken M, Kreiter S, Selmi A, Kowalska J, Jemielity J, Darzynkiewicz E, Huber C, Türeci Ö, Sahin U. 2010. Phosphorothioate cap analogs increase stability and translational efficiency of RNA vaccines in immature dendritic cells and induce superior immune responses in vivo. Gene Ther 17: 961-971. doi:10.1038/gt.2010.52

Kumar P, Sweeney TR, Skabkin MA, Skabkina OV, Hellen CU, Pestova TV. 2014. Inhibition of translation by IFIT family members is determined by their ability to interact selectively with the $5^{\prime}$ terminal regions of cap0-, cap1- and 5'ppp- mRNAs. Nucleic Acids Res 42: 3228-3245. doi:10.1093/nar/gkt1321

Loomis KH, Kirschman JL, Bhosle S, Bellamkonda RV, Santangelo PJ. 2016. Strategies for modulating innate immune activation and protein production of in vitro transcribed mRNAs. J Mater Chem B 4: 1619-1632. doi:10.1039/C5TB0753J

Mauer J, Luo X, Blanjoie A, Jiao X, Grozhik A V, Patil DP, Linder B, Pickering BF, Vasseur J-J, Chen Q, et al. 2016. Reversible methylation of $m^{6} A_{m}$ in the $5^{\prime}$ cap controls mRNA stability. Nature $\mathbf{5 4 1}$ : 371-375. doi:10.1038/nature21022

Pichlmair A, Schulz O, Tan CP, Naslund TI, Liljestrom P, Weber F, Reis e Sousa C. 2006. RIG-I-mediated antiviral responses to singlestranded RNA bearing 5'-phosphates. Science 314: 997-1001. doi:10.1126/science.1132998

Pichlmair A, Lassnig C, Eberle C-A, Górna MW, Baumann CL, Burkard TR, Bürckstümmer T, Stefanovic A, Krieger S, Bennett KL, et al. 2011. IFIT1 is an antiviral protein that recognizes 5'-triphosphate RNA. Nat Immunol 12: 624-630. doi:10.1038/ni .2048

Sahin U, Karikó K, Türeci O. 2014. mRNA-based therapeutics-developing a new class of drugs. Nat Rev Drug Discov 13: 759-780. doi: $10.1038 / \mathrm{nrd} 4278$

Sarkar SN, Sen GC. 2004. Novel functions of proteins encoded by viral stress-inducible genes. Pharmacol Ther 103: 245-259. doi:10 .1016/j.pharmthera.2004.07.007

Schlee $M$, Roth A, Hornung $V$, Hagmann CA, Wimmenauer $V$, Barchet W, Coch C, Janke M, Mihailovic A, Wardle G, et al. 2009. Recognition of $5^{\prime}$ triphosphate by RIG-I helicase requires 


\section{Miedziak et al.}

short blunt double-stranded RNA as contained in panhandle of negative-strand virus. Immunity 31: 25-34. doi:10.1016/j.immuni .2009.05.008

Stepinski J, Bretner M, Jankowska M, Felczak K, Stolarski $R_{\text {, }}$ Wieczorek Z, Cai A, Rhoads R, Temeriusz A, Haber D, et al. 1995. Synthesis and properties of $P^{1}, P^{2}, P^{1}, P^{3}$ AND $P^{1}, P^{4}$, dinucleoside diphosphate, triphosphate and tetraphosphate messenger-RNA 5'-cap analogs. Nucleosides Nucleotides 14: 717-721. doi:10.1080/15257779508012457

Stepinski J, Waddell C, Stolarski R, Darzynkiewicz E, Rhoads RE. 2001. Synthesis and properties of mRNAs containing the novel "antireverse" cap analogs 7-methyl(3'-O-methyl)GpppG and 7-methyl (3'-deoxy)GpppG. RNA 7: 1486-1495. doi:10.1017.S13558 38201014078

Trotman JB, Giltmier AJ, Mukherjee C, Schoenberg DR. 2017. RNA guanine-7 methyltransferase catalyzes the methylation of cytoplasmically recapped RNAs. Nucleic Acids Res 45: 1072610739. doi:10.1093/nar/gkx801

Vallazza B, Petri S, Poleganov MA, Eberle F, Kuhn AN, Sahin U. 2015. Recombinant messenger RNA technology and its application in cancer immunotherapy, transcript replacement therapies, pluripotent stem cell induction, and beyond. Wiley Interdiscip Rev RNA 6: 471-499. doi:10.1002/wrna.1288

Walters RW, Matheny T, Mizoue LS, Rao BS, Muhlrad D, Parker R. 2017. Identification of $\mathrm{NAD}^{+}$capped mRNAs in Saccharomyces cerevisiae. Proc Natl Acad Sci 114: 480-485. doi:10.1073/pnas .1619369114
Wang J, Chew BLA, Lai Y, Dong H, Xu L, Balamkundu S, Cai WM, Cui L, Liu CF, Fu X-Y, et al. 2019. Quantifying the RNA cap epitranscriptome reveals novel caps in cellular and viral RNA. Nucleic Acids Res doi:10.1093/nar/gkz751

Werner M, Purta E, Kaminska KH, Cymerman IA, Campbell DA, Mittra B, Zamudio JR, Sturm NR, Jaworski J, Bujnicki JM. 2011. 2'-O-ribose methylation of cap2 in human: function and evolution in a horizontally mobile family. Nucleic Acids Res 39: 4756-4768. doi:10.1093/nar/gkr038

Yang Z, Liang H, Zhou Q, Li Y, Chen H, Ye W, Chen D, Fleming J, Shu H, Liu Y. 2012. Crystal structure of ISG54 reveals a novel RNA binding structure and potential functional mechanisms. Cell Res 22: 1328-1338. doi:10.1038/cr.2012.111

Yoneyama M, Kikuchi $M$, Natsukawa $T$, Shinobu $N$, Imaizumi $T$, Miyagishi M, Taira K, Akira S, Fujita T. 2004. The RNA helicase RIGI has an essential function in double-stranded RNA-induced innate antiviral responses. Nat Immuno/ 5: 730-737. doi:10.1038/ni1087

Yoneyama M, Kikuchi M, Matsumoto K, Imaizumi T, Miyagishi M, Taira K, Foy E, Loo Y-M, Gale M, Akira S, et al. 2005. Shared and unique functions of the DExD/H-box helicases RIG-I, MDA5, and LGP2 in antiviral innate immunity. J Immunol 175: 2851-2858. doi:10.4049/jimmunol.175.5.2851

Züst R, Cervantes-Barragan L, Habjan M, Maier R, Neuman BW, Ziebuhr J, Szretter KJ, Baker SC, Barchet W, Diamond MS, et al. 2011. Ribose 2'-O-methylation provides a molecular signature for the distinction of self and nonself mRNA dependent on the RNA sensor Mda5. Nat Immunol 12: 137-143. doi:10.1038/ni.1979 

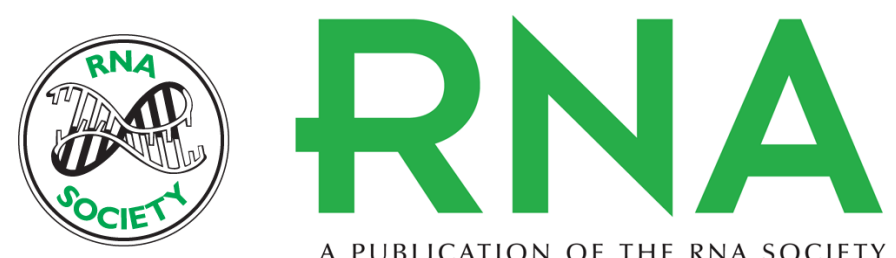

A PUBLICATION OF THE RNA SOCIETY

\section{Kinetic analysis of IFIT1 and IFIT5 interactions with different native and engineered RNAs and its consequences for designing mRNA-based therapeutics}

Beata Miedziak, Anna Dobiezynska, Zbigniew M. Darzynkiewicz, et al.

RNA 2020 26: 58-68 originally published online October 28, 2019

Access the most recent version at doi:10.1261/rna.073304.119

Supplemental Material

References

Creative Commons License

Email Alerting Service
http://rnajournal.cshlp.org/content/suppl/2019/10/28/rna.073304.119.DC1

This article cites 43 articles, 13 of which can be accessed free at: http://rnajournal.cshlp.org/content/26/1/58.full.html\#ref-list-1

This article is distributed exclusively by the RNA Society for the first 12 months after the full-issue publication date (see http://rnajournal.cshlp.org/site/misc/terms.xhtml). After 12 months, it is available under a Creative Commons License (Attribution-NonCommercial 4.0 International), as described at http://creativecommons.org/licenses/by-nc/4.0/.

Receive free email alerts when new articles cite this article - sign up in the box at the top right corner of the article or click here.

To subscribe to $R N A$ go to:

http://rnajournal.cshlp.org/subscriptions 